\title{
Invitro and invivo cultivation of Pergularia tomentosa for cardenolides
}

\author{
M.S., Hifnawy ${ }^{1}$, M.A. El-Shanawany ${ }^{2}$, M.M., Khalifa ${ }^{3}$, A.K, Youssef $^{4}$, \\ M.H Bekhit ${ }^{5} \&$ S.Y., Desoukey*6. \\ ${ }^{1}$ Department of Pharmacognosy, Faculty of Pharmacy, Cairo University. \\ ${ }^{2}$ Department of Pharmacognosy, Faculty of Pharmacy Assuit University. \\ ${ }^{3}$ Department of Pharmacology, Faculty of Pharmacy, Minia University. \\ ${ }^{4}$ Medicinal and Aromatic Plant Dept., Desert Research Center, El-Matariya, Cairo. \\ ${ }^{5}$ Plant biotechnology department, Genetic Engineering and Biotechnology Research Institute, Sadat City \\ University, Minoufiya. \\ 6*Department of Pharmacognosy, Faculty of Pharmacy, Minia University Minia, Egypt.
}

\begin{abstract}
The importance for the conservation of the Egyptian desert plant Pergularia tomentosa was encouraged after the isolation and identification of the highly stable and water soluble cardiac glycosides with very interesting pharmacological activities and wide safety margins.

The study included agricultural and tissue culture experiments for the possible production of these important cardenolides in high concentrations. Calli formation and growth obtained from different explants were significantly affected by many factors tested.

The HPLC analysis of the extracts of both cultivated plants samples and calli from tissue culture experiments demonstrated promising results. All extracts showed the presence of the major ghalakinoside, in variable concentrations. The highest results were obtained from the irrigated plants in the agricultural experiments and after progesterone addition in tissue culture experiments.
\end{abstract}

Key words: Cardenolides of Pergularia tomentosa, in vitro \& in vivo cultivation, propagation\& tissue culturing.

\section{Introduction}

The main sources of cardiac glycosides for manufacture of pharmaceutical grade drugs are from digitalis plants, as well as species of strophanthus [1]. Unfortunately these two plants are not wildly grown in our Egyptian deserts. Generally cardenolides are primarily found in Asclepiadaceae and Apocynaceae families and scattered through a few others [2].

Pergularia tomentosa. of family Asclepiadaceae is well known for its cardiotonic activity and its cardenolides which are of a special type of doubly linked (carbocyclic) sugar which resists acid hydrolysis and reduction, thus are highly stable and also water soluble [3].

The major cardenolide ghalakinoside, has proved promising pharmacological effects on the heart with a wide safety margin and a high therapeutic index, compared to standards [4] and also cytotoxicity testing has shown excellent activity on Hela, liver and brain cells [5] fortunately this plant is common in our Egyptian deserts [6]

The plant`s cardenolide extract also showed a great molluscicidal activity against land snails Monach obstrucat (Ferussac) [7].

P. tomentosa was reported to be one of the economically important plants in Wadi Allaqi conservation area [8] and is becoming rare, and should be conserved to avoid the extinction of such a valuable plant. Cultivation of the plant in the green house of the DRC (Desert research center) produced plants qualitatively similar in cardenolide content to wild plants but quantitatively was different. As the content of these cardenolides vary with ecological factors (stages of development, time of harvest and sometimes the mode of drying [9])this study was conducted for the improvement of environmental conditions of the plant [soil, climate and irrigation], to find the most suitable that increases the production of the above mentioned plant and possible higher cardenolide content. El Sheikh Zuwayed (Sh. Z) Station for extension and research on plant genetic resources was chosen for the performance of these experiments as the climatic conditions and soil analysis could be easily obtained and compared with those of the natural habitat of the plant.

Moreover, this wild medicinal plant problem necessitated trials for propagation by cell cultures and possibly production of active constituents from calli and cell suspensions, as tissue culture techniques are not 
limited by seasons or space and could mean a greater number of plants and possibly more cardenolides production in lesser time in a much purer form.

\section{Materials and methods}

\subsection{Plant material}

\subsubsection{Wild plant material}

The wild plants of Pergularia tomentosa L. were collected from Cairo-Suez road at about $27 \mathrm{Km}$ from Cairo.

The collected plant was identified by Professor Nahed El Hadidy at the herbarium section, Dept. of botany, Faculty of Science, Cairo University as well as by comparison with a voucher specimen at the herbarium of the Desert Research Center (DRC), Cairo, Egypt.

Some wild plants were transferred to the green house of the DRC, for continuous supply of plant organs for tissue culture experiments.

\subsubsection{Cultivated plant material:}

Seeds obtained from collected wild fruits of P.tomentosa from Cairo-Suez road were implanted in the Sh. Z. experimental Station for extension and research on plant genetic resources.

\subsubsection{Methods:}

Mature fruits from wild plants were collected just before ripening, and were placed in a container and covered by a mesh, for good ventilation and prevention of escape of the seeds. When the fruits rupture, the released seeds were kept in a dry well ventilated place, until use.

\subsubsection{Sheikh Zuwayed experimental station:-}

It is situated at the north east coast of Egypt, $35 \mathrm{~km}$ east El Arish Governorate and $15 \mathrm{~km}$ west the border town Rafah (15m above sea level $34^{\circ} 6^{\prime} 57^{\prime \prime} \mathrm{E}$ longitude and $31^{\circ} 14^{\prime} 1^{\prime \prime} \mathrm{N}$ latitude. Average rainfall is 200-300 $\mathrm{mm}$., mean temperature is $15^{\circ} \mathrm{C}$ in winter and $25^{\circ} \mathrm{C}$ in summer. It has a gene bank for saving and conserving local strains and species specially those threatened by extinction, supplied with an automated weather station and irrigated with water from two underground water wells (salinity of the first is $1200 \mathrm{ppm}$ and the other is $4000 \mathrm{ppm}$. Mixed water of these two is adjusted by a computerized conductivity controller to produce the required salinity level for the experiment) using drip irrigation system.

\subsubsection{Design of agricultural experiment}

P.tomentosa seeds were implanted in small pots containing a mixture of 1:1 peat moss and sand, germinated in dark incubators at $25{ }^{\circ} \mathrm{C}$ (it was observed that germination rate increased after incubation in the dark from $50 \%$ to $90 \%$ ) the plantlets of about $10-15 \mathrm{~cm}$ length (average age of two month) were transferred to the soil under climatic conditions of Sh. Z. Station and these plantlets were grouped into two different experimental lines. The first line named rain fed line: which is not irrigated and its water supply depended on rainfall only $[\approx 300 \mathrm{~mm}]$. The second named irrigated line which is irrigated by the drip irrigation system at a rate of 8 liters/hour and water salinity was $\approx 2500 \mathrm{ppm}$. The space between the two lines was $50 \mathrm{~cm}$ and the space between each of the plantlets was $50 \mathrm{~cm}$. also, the length of each line was 6 meters long.

Vegetative growth of plants from both lines was investigated for their general appearance, size, number of branches and size of the leaf.

The aerial parts and roots samples were separately collected from both groups every three months for two successive years.

These collected samples were labeled as rain fed group from I - VIII and as irrigated group from A - H. Each label indicated the month of collection and organ of plant. These samples were air dried, ground to fine powder, weighed and kept in desiccators till used.

A certain weight of each sample was exhausted with methanol and the obtained extracts were separately purified and subjected to HPLC analysis.

Soil analysis was done at the laboratory of soil analysis (DRC) by Professor Mahmoud El-Kady, also weather forecasts were obtained from Sh. Z. station automated weather stations.

A calibration curve for ghalakinoside was constructed by dissolving known weights, in the least amount of HPLC methanol and diluted with mobile phase to $25 \mathrm{ml}$. Eight different volumes were taken, each was completed to $5 \mathrm{ml}$ with mobile phase and $20 \mu \mathrm{l}$ were loaded for HPLC analysis. The volumes injected were equivalent to $0.051,0.063,0.126,0.25,0.5,0.7,1.0$ and $1.26 \mathrm{mg} / \mathrm{ml}$ and were plotted against their corresponding areas. 
A certain volume of each of the methanolic extracts of the different samples were separately injected and similarly analyzed. The concentration of ghalakinoside was determined using the above mentioned calibration curve and represented as \% ghalakinoside/g dry powder in table (4)

\subsection{Tissue culture experiments}

This study was carried out in the Tissue culture laboratory of Plant biotechnology department, Genetic Engineering and Biotechnology Research Institute, Sadat City University, Minoufiya, Egypt.

\subsubsection{Plant materials}

\subsubsection{Preparation of explants.}

i- From wild plant (in vivo)

Different explants (seed, leaf and root) of wild P.tomentosa were used. These explants were washed under current tap water for 2 hours and then immersed in 20\% commercial chlorox solution (1\% sodium hypochlorite) mixed with two drops of tween 20 for 20 minutes and washed three times with sterile distilled water in a laminar-air flow cabinet to remove residual contaminants.

ii- From seedling (in vitro)

Seeds of P.tomentosa which were sterilized as mentioned above were cultured in sterile jars containing $25 \mathrm{ml}$ of sterile MSB5 solid medium and incubated at $25^{\circ} \mathrm{C} \pm 2$ till germination.

\subsubsection{Culture medium}

MS basal salts medium with B5 vitamin was used in this investigation The basic medium (MSB 5 ) was composed of macro- and micronutrients according to (Murshige and Skoog, 1962) [10] and vitamins according to Gamborg et al., [11] with $100 \mathrm{mg} / \mathrm{l}$ inositol, $3 \%$ sucrose and $1 \mathrm{~g} / \mathrm{l}$ casein hydrolisate. The $\mathrm{pH}$ of the medium was adjusted to 5.7-5.8 before adding agar $(1 \%)$ and prior to autoclaving at $121^{\circ} \mathrm{C}$ for 20 minutes. The cultures were incubated in a growth room at $25 \pm 2^{\circ} \mathrm{C}$ for 4 weeks in artificial light using cool white fluorescence lamps of $16 \mathrm{hr} / \mathrm{day}$. All treatments were replicated three times in a rate of $9 \mathrm{jar} /$ replicate.

These experiments were performed to study the effect of different growth hormones and precursors on the callus growth and cardenolides production.

\subsubsection{Experiments \\ Experiment I \\ Callus formation and growth}

Pilot experiments were performed to choose the most suitable media giving the highest callus formation percent.

Different media obtained from reviewing previous studies on this plant [12] and on other cardenolide containing plants were investigated. Those which gave promising results were used.

Leaf explants collected randomly from wild plants as well as root segments (about $1 \mathrm{~cm}$ ) derived from in vitroseedlings were cultured in jars containing $25 \mathrm{ml}$ of MSB5 solid medium (as described prior) alone as control and the same media supplemented with $0.5 \mathrm{mg} / 1$ benzyladenine (BA) with $0.5 \mathrm{mg} / 1 \alpha$ - naphthalene acetic acid (NAA), $1 \mathrm{mg} / \mathrm{l} 2,4 \mathrm{D}$ with $0.2 \mathrm{mg} / \mathrm{l} \mathrm{kinetin,} 1 \mathrm{mg} / \mathrm{l} 2,4 \mathrm{D}$ with 0.1 kinetin, $2 \mathrm{mg} / \mathrm{l} 2,4 \mathrm{D}$ with $0.2 \mathrm{kinetin}$, and 2 $\mathrm{mg} / \mathrm{l} 2,4 \mathrm{D}$ with 0.1 kinetin. Also the seeds were grown on the medium containing $0.5 \mathrm{mg} / \mathrm{l}$ of BA and $0.5 \mathrm{mg} / \mathrm{l}$ NAA. Data were measured by calculating callus formation percentage and visual observation as texture and colour.

\section{Experiment II}

Effect of incubation periods on callus growth and cardenolides production.

Calli which were derived from both in vivo seed and leaf explants and from in vitro root seedlings were subcultured on fresh medium in jars containing $25 \mathrm{ml}$ of MSB5 solid medium and supplemented with $0.5 \mathrm{mg} / \mathrm{l}$ of BA and $0.5 \mathrm{mg} / \mathrm{l} \mathrm{NAA}$. Data were recorded every month for 3 times as callus fresh weight (g/explants) and Callus growth value (Gv) according to Djoko \& Thornburg, 1992 [ 13 ]

\section{Experiment III:}

Effect of the growth regulators (NAA\&BA) on callus growth and cardenolides production derived from different $P$. tomentos $a$ explants.

Calli selected from in vitro-explants (seed, leaf and root) in experiment II were divided into small pieces (ranged from 0.498 to $0.556 \mathrm{gm}$ ) and subcultured in jars containing $25 \mathrm{ml}$ of MSB5 solid medium supplemented with $\alpha$-naphthalene acetic acid (NAA) separately in rate of $0.5,1.0$ and $2.0 \mathrm{mg} / \mathrm{l}$ and combined with 0.1 and $0.5 \mathrm{mg} / \mathrm{l}$ of BA as well as control treatment. Callus fresh weight (g/explants) was weighed every 15 days for 45 days and callus growth rate (g/day) was calculated according to Dunk MN et al [14]. 


\section{Experiment IV \\ Effect of the precursor (progesterone) on cardenolides production in callus derived from different P. tomentosa explants}

This experiment was carried out to study the effect of progesterone as precursor on cardenolide production. Calli selected from the three above explants (seed, leaf and root) were transferred to jars containing $25 \mathrm{ml}$ of $\mathrm{MSB}_{5}$ solid medium with $0.5 \mathrm{mg} / \mathrm{l}$ of NAA $+0.5 \mathrm{mg} / \mathrm{l}$ of BA and supplemented with $100 \mathrm{mg} / \mathrm{l}$ of progesterone. All cultures were replicated 3 times and incubated at $25^{\circ} \mathrm{C} \pm 2$ using $16 \mathrm{hr}$ light/day for 2 weeks.

\subsubsection{Determination of Cardenolide}

Reference used was ghalakinoside obtained from the isolation of the roots of wild P. tomentosa

\subsubsection{Preparation of samples for cardenolide detection:}

At the end of each experiment the calli were separately weighed, ground with sand and exhaustively extracted with methanol. Solvent removed from each extract under reduced pressure. The methanolic extracts were directed to:-

\section{i. Phytochemical screening and TLC analysis:-}

using different solvent systems $\left(\mathrm{CHCl}_{3}-\mathrm{MeOH}\right.$ 8:2 and/or 9:1) and different spray reagents (Kedde`s \& Baljet`s reagents).

\section{ii. HPLC analysis:-}

Each extract was diluted to $10 \mathrm{ml}$ with mobile phase and injected against ghalakinoside and calactin using HPLC; Analytical column, $25 \mathrm{~cm} \mathrm{X} 4.6$ stainless steel $\mathrm{RPC}_{18} 5_{\mathrm{Um}}$. Licrocart $25 \mathrm{~A}$ or $\mathrm{C}_{18}$ (Shimpack) Packed with $\mathrm{C}_{18}$ stationary phase, Pump Merck Hitachi pump L. 7110, Injector volume 20 ul or 25 ul. Detector: - UV at $K_{\max } 220 \mathrm{~nm}$ or $280 \mathrm{~nm}$. Integrator interface, D.7000 Software. The substances were dissolved in $\mathrm{MeOH}$ for $\mathrm{HPLC}$ and were allowed to run for $20 \mathrm{~min}$. with flow rate of $0.5 \mathrm{ml} / \mathrm{min}$. Mobile phase $\mathrm{MeOH}-\mathrm{H}_{2} \mathrm{O} 70: 30$

\subsection{Agricultural Study:}

\section{Results}

The climatic conditions and soil analysis of Sh. Z. station were obtained and compared with those of the natural habitat of the plant under study.

The climatic conditions of (Sh. Z) Station were compared with those of the natural habitat of the wild plants of Suez Cairo, where it was obvious that both climates were of high average temperature and relative humidity $\%$, while their average solar ray intensity and total rain were different as these two parameters were much higher in Sh. Z. station.

No difference was observed between the soil analysis of Sh. Z. Station -of both irrigated and rain fed plants, Table (1) and also between those of the natural habitats of the plant in Cairo-Suez Road, Taba and Haliab regions [5] all were of poor fertility and neutral or slightly alkaline $\mathrm{pH}$ of soils. The Soil profiles are deep, i.e., more than $90 \mathrm{~cm}$. depth. These Soils are derived from the sand dunes and Aeolian deposits. The soil texture is dominated by coarse sand, and contains no fine materials as clay or silt.

Table (1) Some Physical, chemical and nutrient Properties of the two tested soil of Sheikh Zuwayed Station.

\begin{tabular}{|c|c|c|c|c|c|c|c|c|c|c|c|c|c|c|c|c|}
\hline \multirow{2}{*}{\multicolumn{2}{|c|}{$\begin{array}{l}\text { Soil Samples } \\
\text { (Depth in } \mathrm{cm} \text { ) }\end{array}$}} & \multicolumn{4}{|c|}{ Mechanical Analysis (Dry Sieving) } & \multirow[b]{2}{*}{$\begin{array}{c}\text { Texture } \\
\text { class }\end{array}$} & \multirow[b]{2}{*}{$\mathrm{PH}$} & \multirow{2}{*}{$\begin{array}{l}\text { Salinity } \\
\text { mmhos } \\
/ \mathrm{cm}\end{array}$} & \multirow[b]{2}{*}{$\begin{array}{c}\mathrm{CaCO}_{3} \\
\%\end{array}$} & \multicolumn{7}{|c|}{ Available Nutrients (ppm) } \\
\hline & & $\begin{array}{c}\text { Coarse } \\
\text { Sand }\end{array}$ & $\begin{array}{l}\text { Fine } \\
\text { Sand }\end{array}$ & $\begin{array}{c}\text { Very Fine } \\
\text { Sand }\end{array}$ & $\begin{array}{c}\text { Clay } \\
+\end{array}$ & & & & & $\mathrm{N}$ & $\mathrm{P}$ & $\mathrm{K}$ & $\mathrm{Zn}$ & $\mathrm{Cu}$ & $\mathrm{Fe}$ & $\mathrm{Mn}$ \\
\hline \multirow{4}{*}{ 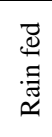 } & $1-20$ & 72.7 & 20.3 & 7.0 & - & Sandy & 7.1 & 1.82 & 1.9 & 45 & 3.2 & 8.9 & 0.8 & 0.4 & 1.1 & 0.7 \\
\hline & $2-20$ & 71.8 & 21,4 & 6.8 & - & Sandy & 7.2 & 1.75 & 1.9 & 48 & 2.9 & 9.0 & 0.7 & 0.4 & 1.2 & 0.7 \\
\hline & $3-50$ & 70.4 & 22.5 & 7.1 & - & Sandy & 7.2 & 1.80 & 1.8 & 47 & 3.1 & 9.1 & 0.8 & 0.3 & 1.1 & 0.8 \\
\hline & $4-50$ & 71.1 & 20.4 & 8.5 & - & Sandy & 7.4 & 1.83 & 2.0 & 48 & 3.2 & 9.2 & 0.6 & 0.3 & 1.3 & 0.8 \\
\hline \multirow{4}{*}{ 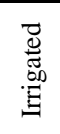 } & $5-20$ & 68.3 & 20.8 & 10.9 & - & Sandy & 7.3 & 2.73 & 2.1 & 63 & 3.2 & 9.4 & 0.7 & 0.4 & 1.2 & 0.6 \\
\hline & $6-20$ & 70.1 & 19.2 & 10.7 & - & Sandy & 7.5 & 2.82 & 1.9 & 68 & 3.1 & 9.3 & 0.8 & 0.4 & 1.3 & 0.8 \\
\hline & $7-50$ & 69.2 & 18.5 & 12.3 & - & Sandy & 7.4 & 2.90 & 1.8 & 69 & 3.2 & 9.6 & 0.9 & 0.4 & 1.2 & 0.7 \\
\hline & $8-50$ & 70.5 & 18.0 & 11.5 & - & Sandy & 7.4 & 2.88 & 1.8 & 72 & 3.4 & 9.8 & 0.8 & 0.5 & 1.3 & 0.8 \\
\hline
\end{tabular}

The analysis of soil revealed that the soils are characterized by:

Low salinity but some slight salinity was observed in the irrigated soil samples compared to the rain fed one,

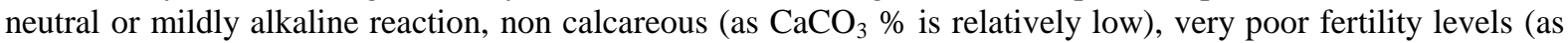
the soil samples contain very low amounts of nutritive elements). These results show that the irrigated plant samples looked generally healthier, greener and of a much larger size, having a higher number of branches and slightly larger leaves which are more fleshy [more latex content]. 
Table (2) percentage of ghalakinoside/g dry powder

I= irrigated $\mathbf{R}=$ rainfed

\begin{tabular}{|c|c|c|c|c|c|c|c|c|c|c|c|c|c|c|c|c|c|c|}
\hline Month & \multicolumn{2}{|c|}{$\begin{array}{c}\text { Dec } \\
1999\end{array}$} & \multicolumn{2}{|c|}{$\begin{array}{c}\text { March } \\
2000\end{array}$} & \multicolumn{2}{|c|}{$\begin{array}{l}\text { June } \\
2000\end{array}$} & \multicolumn{2}{|c|}{$\begin{array}{l}\text { Sept. } \\
2000\end{array}$} & \multicolumn{2}{|c|}{$\begin{array}{l}\text { Dec. } \\
2000\end{array}$} & \multicolumn{2}{|c|}{$\begin{array}{c}\text { March } \\
2001\end{array}$} & \multicolumn{2}{|c|}{$\begin{array}{l}\text { June } \\
2001\end{array}$} & \multicolumn{2}{|c|}{$\begin{array}{l}\text { Sept. } \\
2001\end{array}$} & \multicolumn{2}{|c|}{$\begin{array}{l}\text { Dec. } \\
2001\end{array}$} \\
\hline Conc. Of & $\mathrm{I}$ & $\mathrm{R}$ & $\mathrm{I}$ & $\mathrm{R}$ & $\mathrm{I}$ & $\mathrm{R}$ & $\mathrm{I}$ & $\mathrm{R}$ & $\mathrm{I}$ & $\mathrm{R}$ & $\mathrm{I}$ & $\mathrm{R}$ & $\mathrm{I}$ & $\mathrm{R}$ & I & $\mathrm{R}$ & $\mathrm{I}$ & $\mathrm{R}$ \\
\hline $\begin{array}{c}\text { ghalakınoside/ } \\
\text { g dry powder }\end{array}$ & 0.0146 & 0.012 & 0.0958 & 0.0075 & 0.1003 & 0.00411 & 0.0409 & 0.0041 & 0.09375 & 0.025 & 0.0694 & 0.00436 & 0.13109 & 0.0123 & 0.0868 & 0.0072 & 0.18028 & 0.004 \\
\hline
\end{tabular}

From Table (2) and Fig. (1, 2\&3) it could be concluded that the irrigated plants showed a higher percentage of ghalakinoside, compared to those of the rain fed plants. The highest concentration was observed at December in both rain fed and irrigated plants, while the lowest was seen at March which could be due to the low average temperature $7.15^{\circ} \mathrm{C}$ after being $14.13{ }^{\circ} \mathrm{C}$ at the previous year, this revealed a decrease to a half in concentration of ghalakinoside, with a low rainfall of $4.31 / \mathrm{mm}$ after $18.86 / \mathrm{mm}$ and also average humidity was somewhat high $83.01 \%$ after 68.07 . One or more of these factors could be the cause of the drop in the percentage of cardenolides.

On the other hand the rain in December was of the lowest value compared to the other years $2.53 / \mathrm{mm}$ from $13.72 / \mathrm{mm}$ at 1999 and $7.55 / \mathrm{mm}$ at 2001 while the cardenolides were high in irrigated and highest at the rain fed which would assume that low cardenolide values are not dependent on the rainfall only

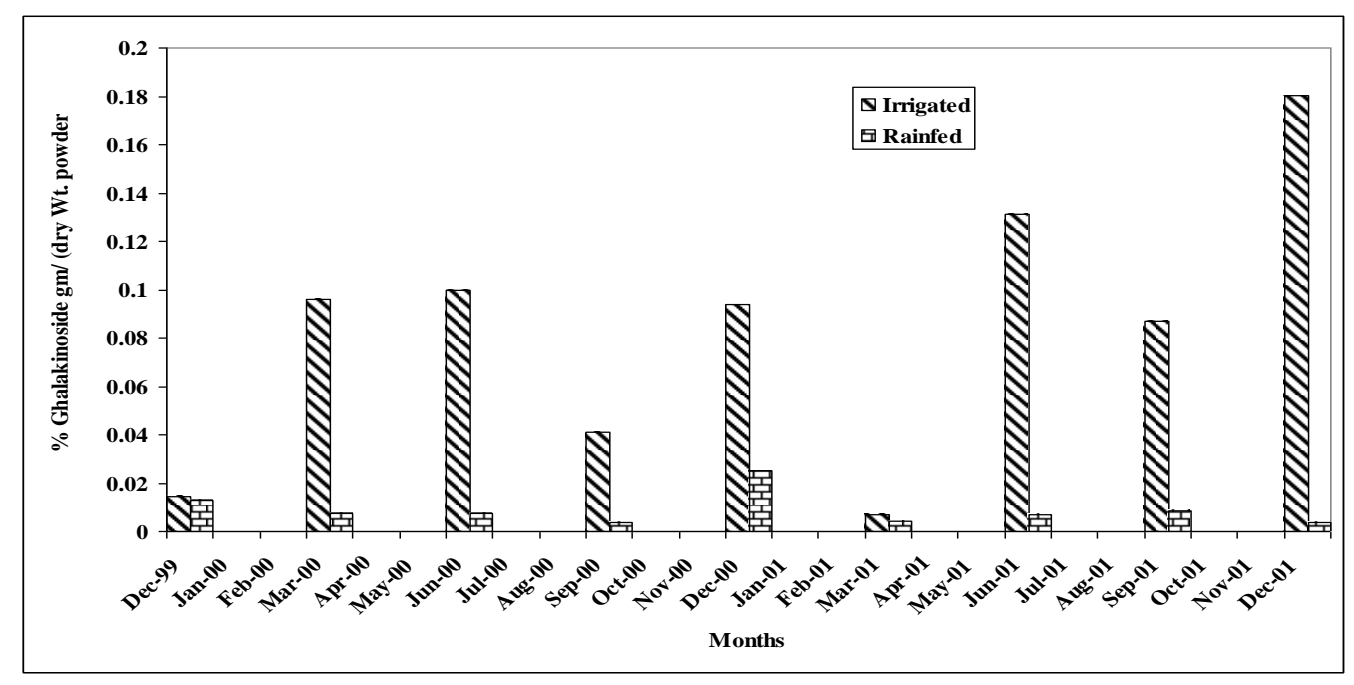

Fig. (1) The follow up of the \% of ghalakinoside in rainfed and irrigated aerial parts samples of the plants cultivated in the Sheikh Zuwayed (Sh. Z.)

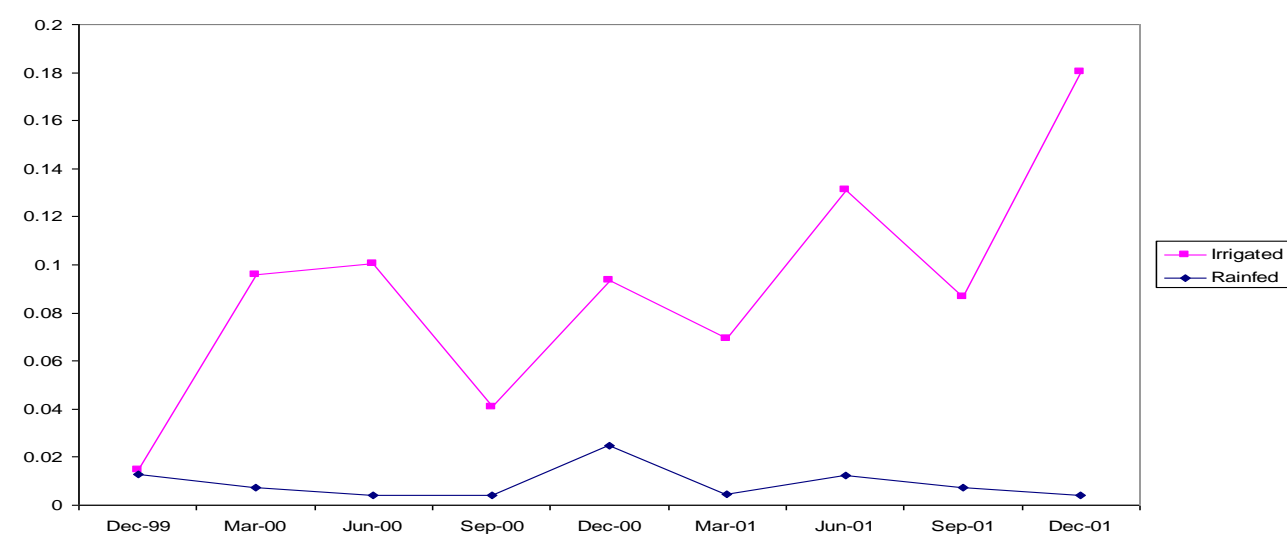

Fig. (2) Ghalakinoside variation in rainfed and irrigated plants throughout the two years period 


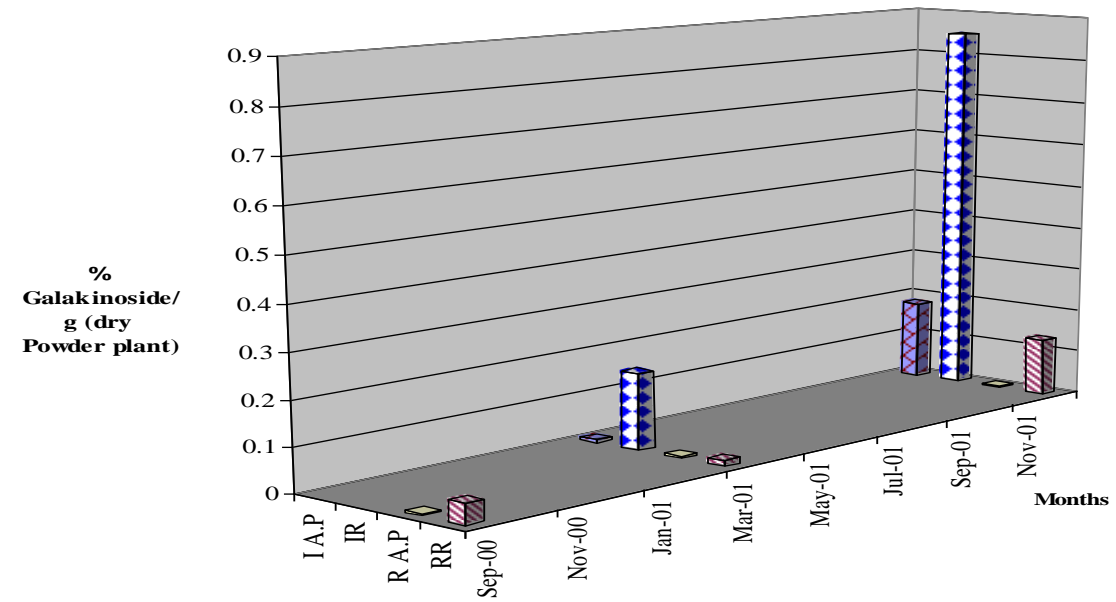

$\begin{array}{ll}\text { QR R } & =\text { rainfed roots } \\ \text { QR A.P } & =\text { rainfed aerial parts }\end{array}$ Q IR $\quad=$ irrigated roots GI A.P = irrigated aerial parts

Fig. (3)The difference in the \% of ghalakinoside, between irrigated and rain fed aerial parts and root.

\subsection{Tissue Culture study of $\boldsymbol{P}$. tomentosa organs}

Experiment I

Preliminary studies on callus production and growth

From pilot experiments that were performed to choose the most suitable media giving the highest callus formation percent, all explants tested, failed to form callus on $\mathrm{MSB}_{5}$ medium growth regulator-free,

Different media obtained from reviewing previous studies on this plant [12] and on other cardenolide containing plants were investigated. Those which gave promising results were used.

Due to involvement of progesterone in the biosynthesis of cardenolides as intermediate precursor progesterone addition to selected media was examined.

Table (3) Callus formation percentage grown on $\mathrm{MSB}_{5}$ solid supplemented with different concentrations of 2,4-D and Kinetin

\begin{tabular}{|c|c|c|c|c|c|c|c|}
\hline \multirow{3}{*}{ Kinetin (mg/l) } & \multirow{3}{*}{$\begin{array}{c}2,4-D \\
(\mathrm{mg} / \mathrm{l})\end{array}$} & \multicolumn{6}{|c|}{ Explants } \\
\hline & & \multicolumn{3}{|c|}{ Leaf } & \multicolumn{3}{|c|}{ Root } \\
\hline & & $\begin{array}{c}\text { Callus formation } \\
\% \\
\end{array}$ & Texture & colour & $\begin{array}{c}\text { Callus formation } \\
\% \\
\end{array}$ & Texture & colour \\
\hline \multirow{2}{*}{0.1} & 1 & 50 & \multirow{2}{*}{$\begin{array}{l}\text { Compact } \\
\text { "'"'"'"!" }\end{array}$} & Greenish & 50 & \multirow{2}{*}{$\begin{array}{l}\text { Compact } \\
\text { "'"'"'"" }\end{array}$} & Greenish \\
\hline & 2 & 25 & & White & 25 & & White \\
\hline \multirow{2}{*}{0.5} & 1 & 100 & \multirow{2}{*}{$\begin{array}{l}\text { Compact } \\
\text { "'"'"'"'"" }\end{array}$} & White & 100 & \multirow{2}{*}{$\begin{array}{c}\text { Gelatinous } \\
\text { "'"'"'"'"'" }\end{array}$} & Yellowish \\
\hline & 2 & 75 & & White & 75 & & White \\
\hline
\end{tabular}

Table (4) Callus formation percentage grown on $\mathrm{MSB}_{5}$ basal medium supplemented with $0.5 \mathrm{mg} / \mathrm{l} \mathrm{BA}$ and $0.5 \mathrm{mg} / \mathrm{l} \mathrm{NAA}$

\begin{tabular}{llll}
\hline Explant & \multicolumn{2}{c}{ Callus formation } & \multicolumn{2}{c}{ Visual observation } \\
\cline { 2 - 4 } & & Texture & Colour \\
Seed & 100 & friable & white \\
Leaf & 100 & Compact & Greenish at first then changes to \\
& & & yellowish white
\end{tabular}

Root $100 \quad$ Soft gelatinous Reddish yellow

Data in tables (3) and (4) clearly showed that, the callus formation percentage was highest in case of $\mathrm{MSB}_{5}$ supplemented with $0.5 \mathrm{mg} / \mathrm{l}$ BA and $0.5 \mathrm{mg} / \mathrm{l}$ NAA for all explants and with $1 \mathrm{mg} / \mathrm{l}$ 2,4-D and $0.5 \mathrm{mg} / \mathrm{l}$ kinetin for both leaf and root explants [100\%], followed by the medium containing $2 \mathrm{mg} / \mathrm{l}$ 2,4-D and 0.5 kinetin [75\%], then $1 \mathrm{mg} / \mathrm{l} 2,4-\mathrm{D}$ and $0.1 \mathrm{mg} / \mathrm{l}$ kinetin [50\%] and lastly that medium supplemented with $2 \mathrm{mg} / \mathrm{l}$ 2,4-D and $0.1 \mathrm{mg} / \mathrm{l} \mathrm{kinetin} \mathrm{[25 \% ]} \mathrm{from} \mathrm{which} \mathrm{we} \mathrm{could} \mathrm{conclude} \mathrm{that} \mathrm{the} \mathrm{higher} \mathrm{concentration} \mathrm{of}$ kinetin was required with the lower concentration of 2,4-D.

It was clear that produced calli were generally less compact with BA and NAA and tend to have a more friable texture with variable colours, therefore BA with NAA media were selected for the rest of the experiments. 


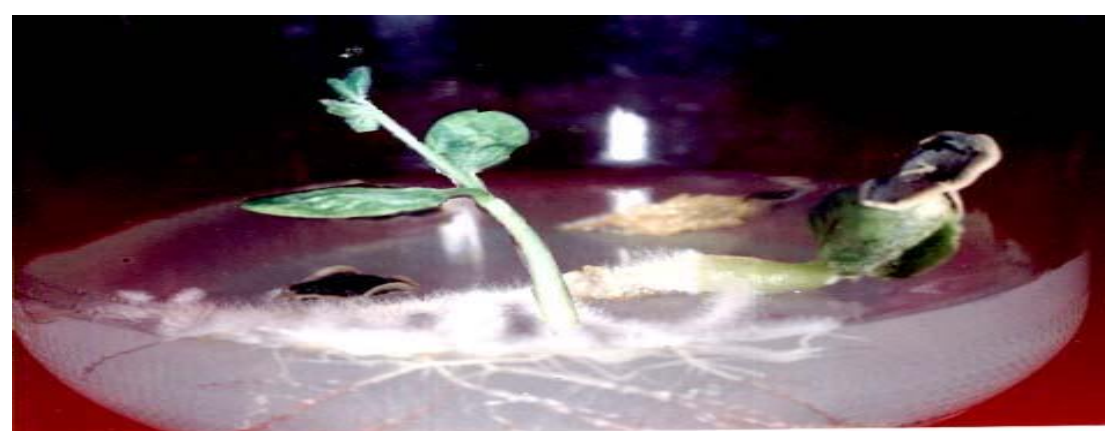

Fig. (5) The seedling of Pergularia tomentosa

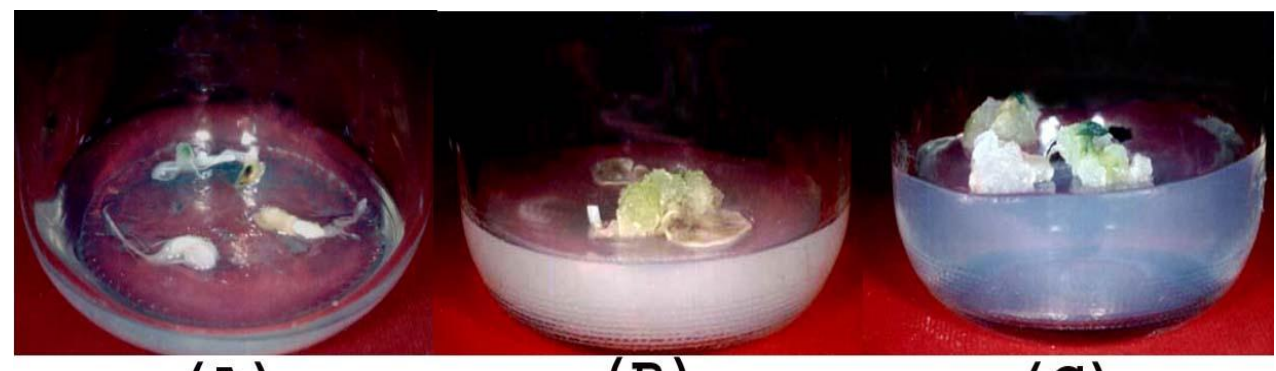

(A) (B) (C)

Fig. (6) Callus formation from: A) Root B) leaf C) seed

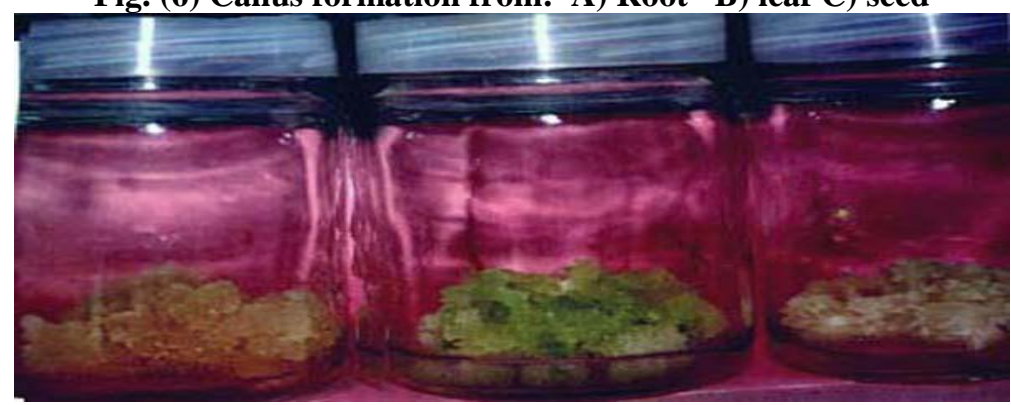
A) Root
B) leaf
C) seed

Experiment II

Fig. (7) Types of callus derived from different explant sources.

Effect of incubation period on callus growth and cardenolide production

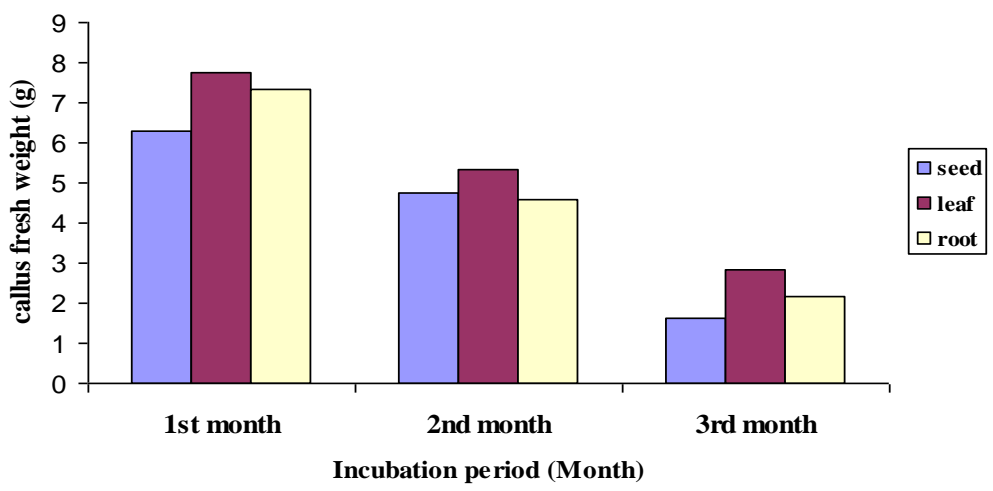

Fig. (8) Effect of incubation periods on callus fresh weight derived from different P. tomentosa explants grown on MSB5 solid medium. 


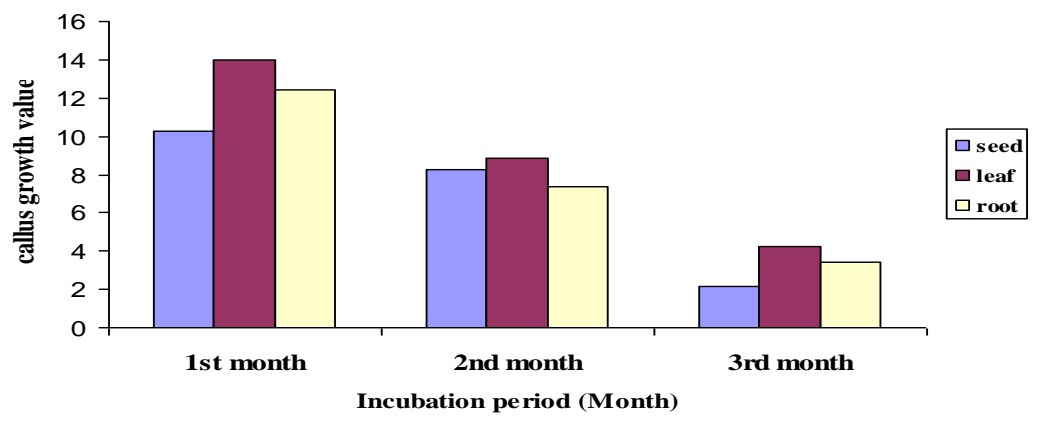

Fig. (9) Effect of incubation periods on callus growth value derived from different $P$. tomentosa explants grown on $\mathrm{MSB}_{5}$ solid medium.

From Fig. (8)\&Fig.(9), the highest callus fresh weight was achieved from leaf explant, followed by the root and lastly the seed. Also, the data showed clearly that in general, the callus weight decreased by increasing the incubation time. Growth value of leaf explant decreased from [14.024] to [4.269] after three months and similarly the root from [12.401] to [3.388] and the seed from [10.266] to [2.126], respectively.

\section{Experiment III}

Effect of growth regulators on callus growth and cardenolides production

(a)

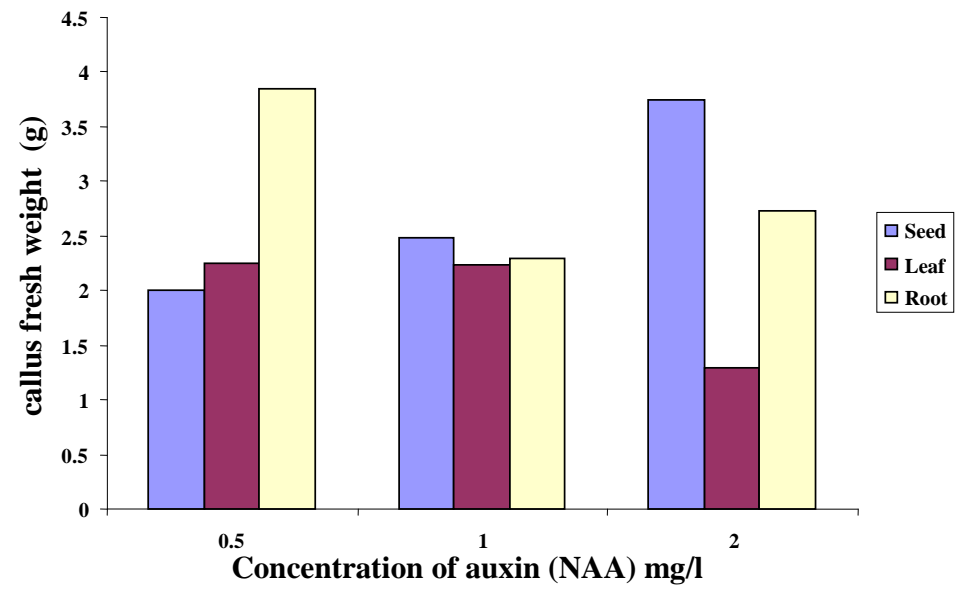

(b)

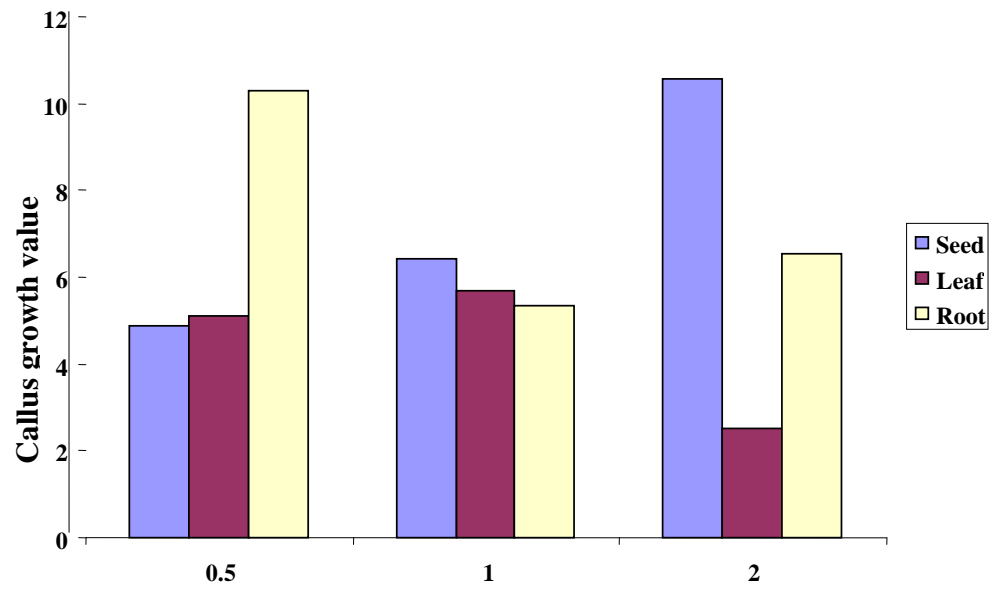

Concentration of auxin (NAA) $\mathrm{mg} / \mathrm{l}$

Fig. (10) : Effect of auxin (NAA) concentration on (a) callus fresh weight and (b) callus growth value derived from different explants of $P$. tomentosa grown on $\mathrm{MSB}_{5}$ solid media.

Callus growth value $(\mathrm{Gv})=\mathrm{FW} 1-\mathrm{FW} 0 / \mathrm{FW} 0$. Where $\mathrm{FW}_{1}$ is final callus fresh weight $\& \mathrm{FW}_{0}$ is initial callus fresh weight. 


\section{Seed}
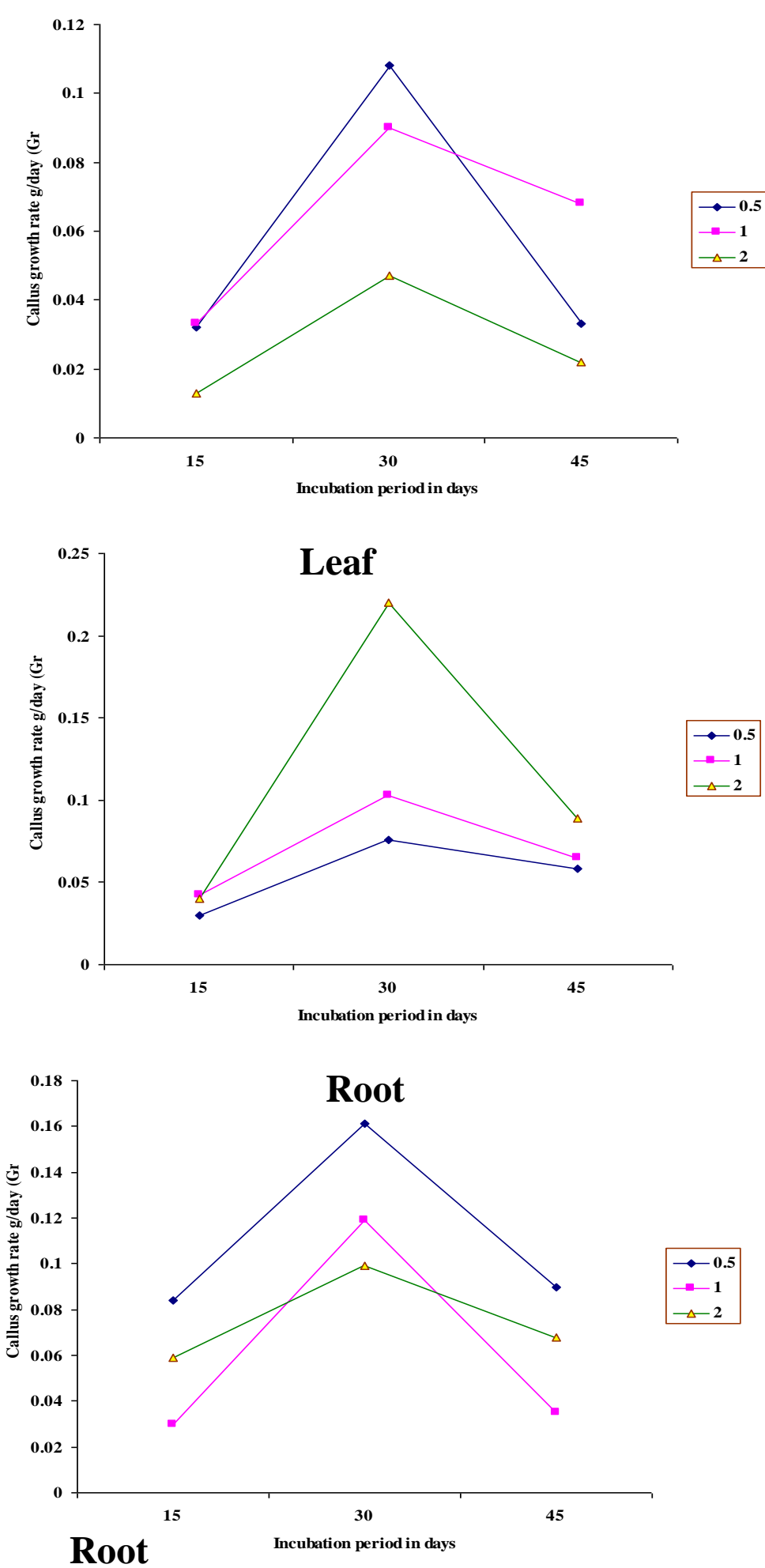

Fig. (11): Effect of auxin (NAA) concentration on callus growth rate derived from different explants of $P$. tomentosa grown on $\mathrm{MSB}_{5}$ solid media.

Callus growth rate $(\mathrm{Gr})=\mathrm{FW} 1-\mathrm{FW} 0 /$ Days

Where $\mathrm{FW}_{1}=$ final callus fresh weight, $\mathrm{FW}_{0}=$ initial callus fresh weight

The data in Fig. (10) demonstrated that the addition of auxin (NAA) affected the fresh weight of callus at the three different concentrations used [0.5, 1.0 and $2.0 \mathrm{mg} / \mathrm{l}]$ and caused a gradual increase during the three incubation periods 
which affected the production of callus regardless the explant type. However the highest callus production was achieved from root explant closely followed by the seed and lastly the leaf 2.951, 2.742 and $1.924 \mathrm{~g}$, respectively.

Concerning the callus growth values and rates, Fig. (11) demonstrated the highest values and rates observed with the root explants followed by the seed and lastly the leaf. Whereas both growth value and rate were highest with $\mathrm{MSB}_{5}$ medium supplemented with $0.5 \mathrm{mg} / \mathrm{l} \mathrm{NAA}$ with root explant and $2 \mathrm{mg} / \mathrm{l} \mathrm{NAA}$ with that of the seed and $1 \mathrm{mg} / \mathrm{l} \mathrm{NAA}$ with the leaf explant.

HPLC analysis showed the presence of ghalakinoside in leaf explants and trace amounts in root explants probably due to the roots invitro origin.

(a)

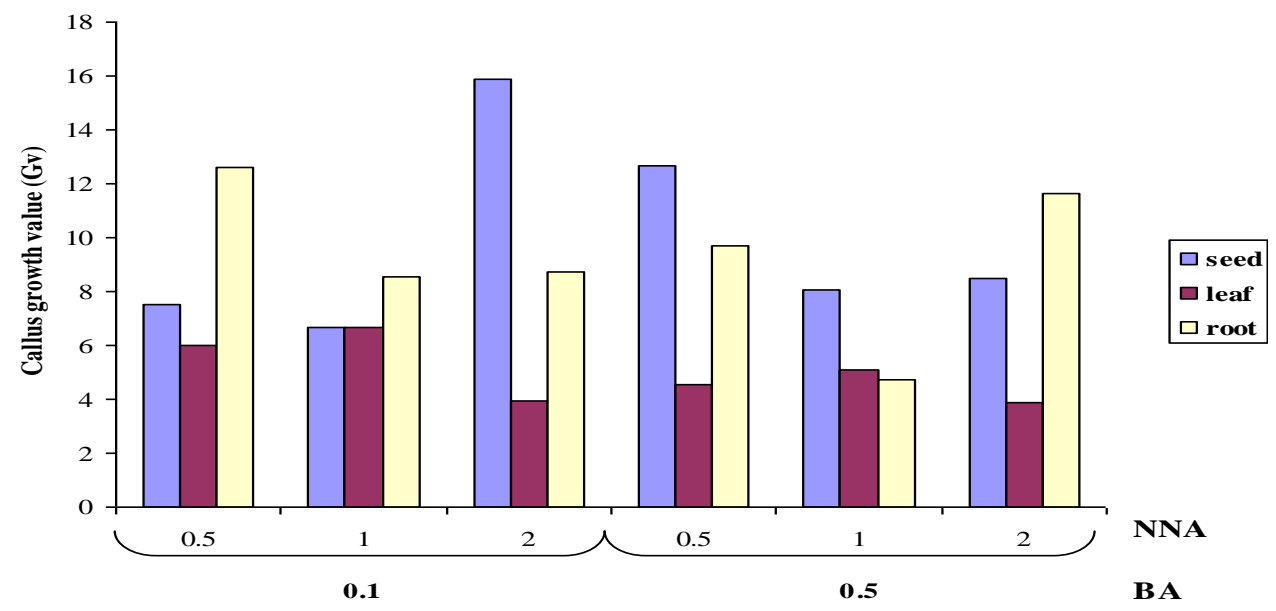

(b)

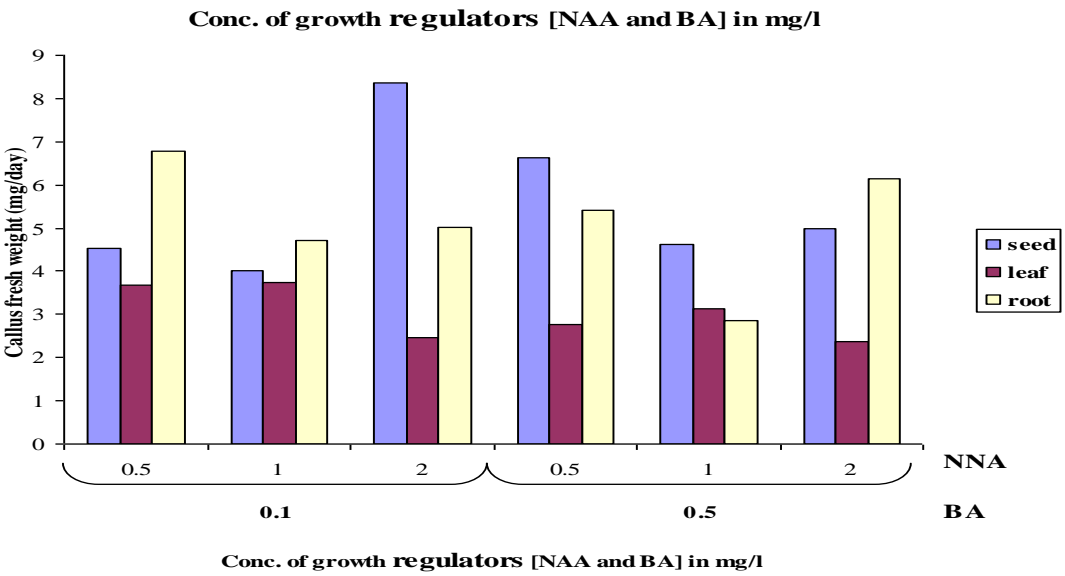

Fig. (12): Effect of growth regulators [NAA and BA concentrations] on (a) callus fresh weight $\&$ (b) callus growth value $(\mathrm{Gv})$ derived from different $P$. tomentosa explants grown on $\mathrm{MSB}_{5}$ solid medium.

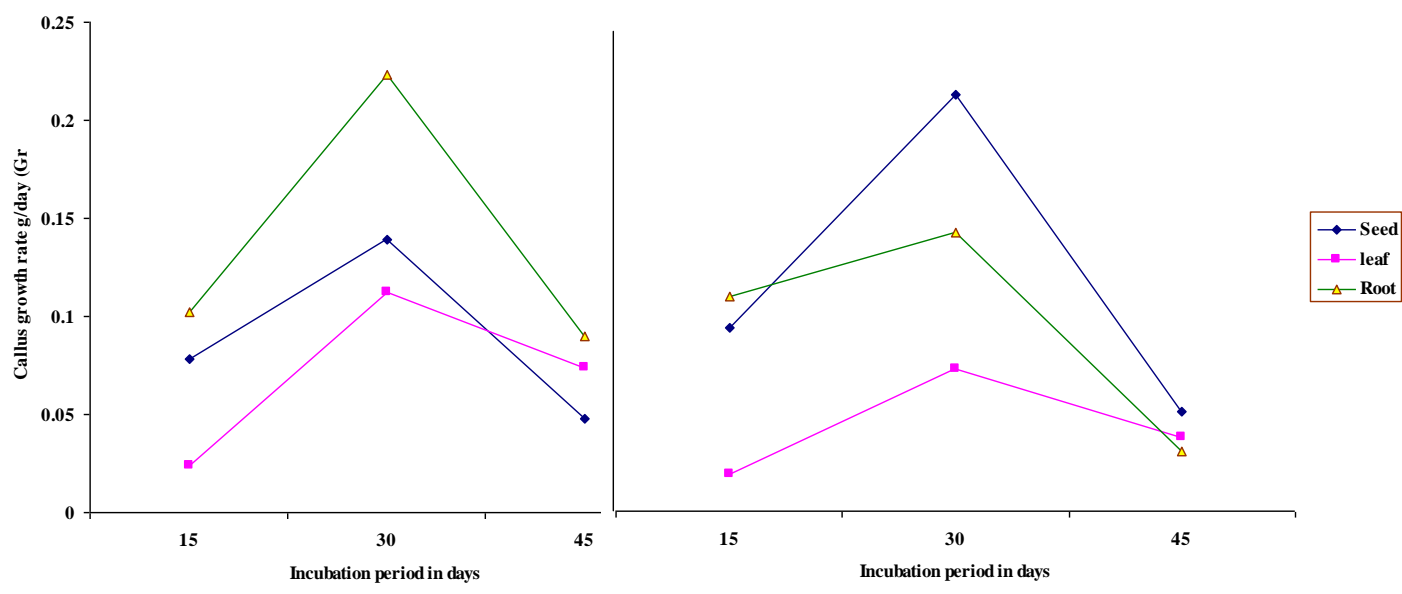



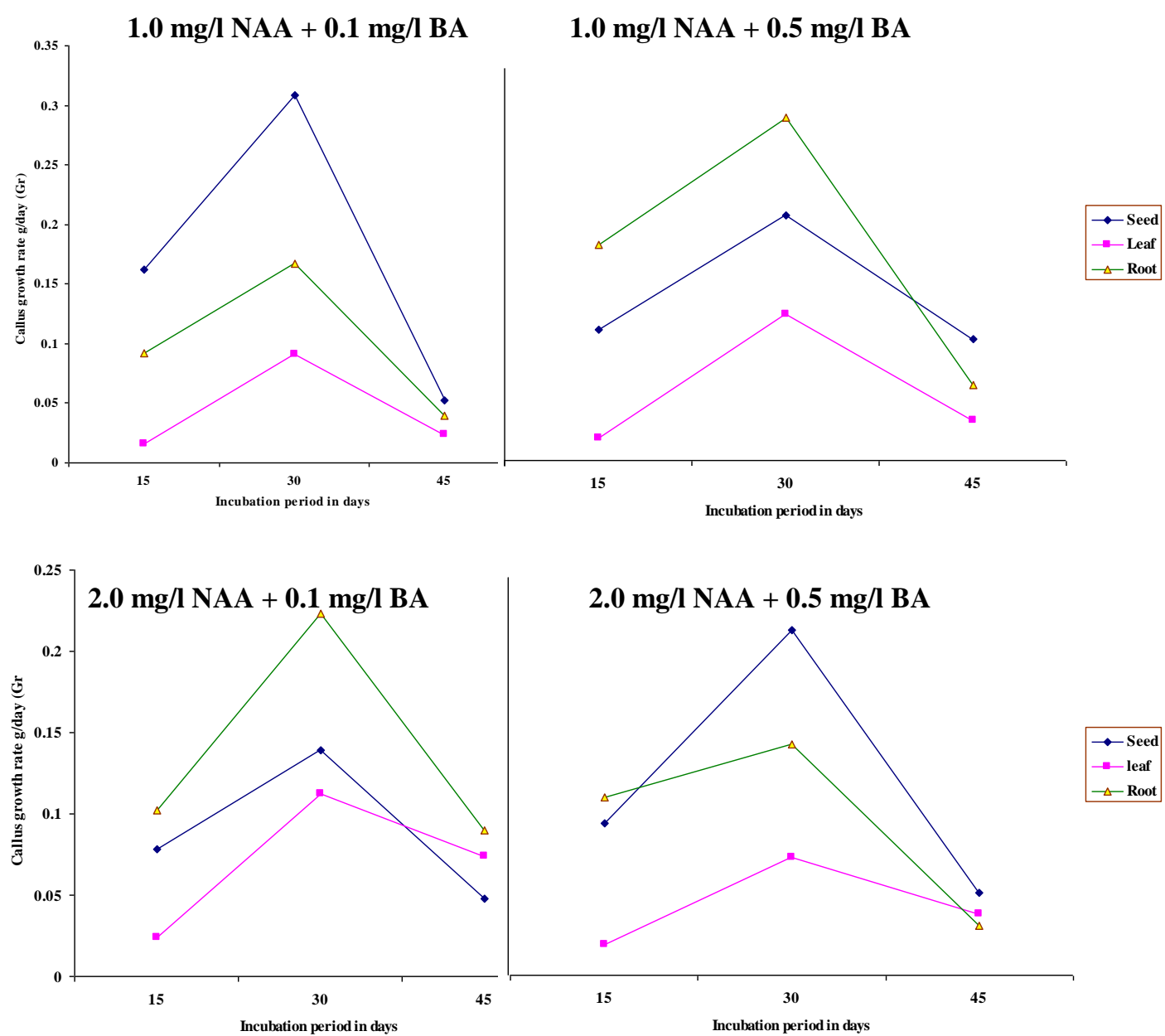

$2.0 \mathrm{mg} / \mathrm{l} \mathrm{NAA}+0.5 \mathrm{mg} / \mathrm{l} \mathrm{BA}$

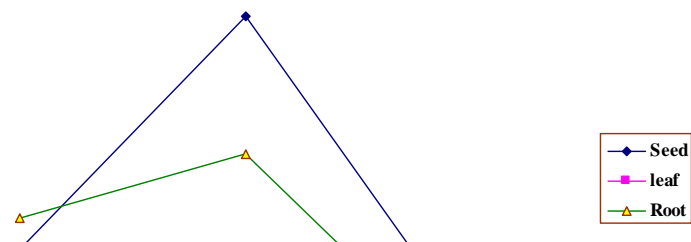

Fig. (13): Effect of NAA and BA concentrations on callus growth rate(Gr) derived from different $P$. tomentosa explants grown on $\mathrm{MSB}_{5}$ solid media after incubation period of 15,30 and 45 days.

Data illustrated in Fig. (12) demonstrated that generally the highest fresh weight was recorded for callus derived from seed $(4.147 \mathrm{~g})$ closely followed by root $(4.008 \mathrm{~g})$ then lastly was the leaf explant $(2.348 \mathrm{~g})$. The highest level of NAA $(2 \mathrm{mg} / \mathrm{l})$ and the lowest level of BA $(0.1 \mathrm{mg} / \mathrm{l})$ gave the highest significant effect on callus production. Among all treatments, it was evident that the highest amount of callus $(8.351 \mathrm{~g})$ was achieved when the seed callus was cultured on media supplemented with $2 \mathrm{mg} / \mathrm{l}$ of NAA with $0.1 \mathrm{mg} / \mathrm{l}$ of BA and incubated for 45 days. The above results declared that callus fresh weight increased gradually during the three incubation periods and all treatments significantly affected callus production regardless of the explant type.

Concerning the callus growth values, the data demonstrated the same trend where the highest value was that of the seed followed by the root and lastly the leaf explant, when supplemented with $2 \mathrm{mg} / \mathrm{l} \mathrm{NAA}$ and 0.1 $\mathrm{mg} / \mathrm{l} \mathrm{BA}$.

Regarding the callus growth rate, the data in Fig. (13) illustrated that the results agreed with that of the growth values where the highest rate was observed with callus produced from seeds explant followed by the roots and lastly the leaf, after an incubation period of 30 days. Also, the most suitable media for leaf explant $\mathrm{MSB}_{5}$ containing $0.5 \mathrm{mg} / \mathrm{l} \mathrm{BA}$ (as cytokinin) with those having 2.0, 0.5 and $1.0 \mathrm{mg} / \mathrm{l} \mathrm{NAA}$ (auxin) respectively.

HPLC analysis demonstrated the presence of ghalakinoside in the leaf, root and seed explant calli.

\section{Experiment IV:}

Effect of the precursor (progesterone) on cardenolides production in calli derived from different $P$. tomentosa explants

Calli from control [0.5 mg/l BA and $0.5 \mathrm{mg} / 1 \mathrm{NAA}]$ and treated media $[0.5 \mathrm{mg} / \mathrm{l} \mathrm{BA}$ and $0.5 \mathrm{mg} / \mathrm{l} \mathrm{NAA}$ with $100 \mathrm{mg} / \mathrm{l}$ progesterone] of seed, leaf and root explants were extracted as mentioned before.

\section{Cardenolide detection:}

1- Phytochemical screening and TLC analysis: 
Pink coloration was observed when leaf and root calli extracts were treated with kedde's reagent. Also, TLC spots were identified with kedde's spray reagent using the two stated solvent systems.

2- HPLC analysis:

Each explant extract was found to have the same $R_{t}$ of ghalakinoside and calactin as references.

It was quite evident from HPLC analysis that the addition of progesterone as precursor affected both the leaf and root calli without any effect on the seed callus [which showed no change after treatment with 100 $\mathrm{mg} / \mathrm{l}$ progesterone]. The leaf callus extract after treatment doubled the concentration of ghalakinoside peak, while the root ghalakinoside peak increased two and half times after treatment. Also, a peak having the same $R_{t}$ of calactin was observed. This increase means that the addition of progesterone as precursor in media enhanced the production of the major cardenolide ghalakinoside.

\section{Cardenolide Production}

From the obtained calli of the three different explants of the previous experiments it could be concluded that: the different growth regulators affected the shape, colour and texture of calli and different incubation periods effected growth rates and values but no cardenolides could be detected.

Treatments with different concentrations of NAA showed HPLC peaks of an $R_{t}$ similar to ghalakinoside.

On the other hand, treatment with progesterone as a precursor produced an increase in the peak of ghalakinoside with leaf and root calli.

\section{Conclusion}

The importance of $P$. tomentosa as a cardiotonic medicinal plant was reported ages ago but nothing was performed for the rescue of this plant which is threatened by extinction. The highly stable \& water soluble cardiac glycosides (ghalakinoside \& calactin) of the above mentioned species, forced us to work on cultivation of this plant, for ensuring its supply as a medicinal plant with possible therapeutic applications. Collecting the aerial parts of this plant without destroying its roots could mean conserving the whole plant.

The cultivation of $P$. tomentosa under the specified conditions of El-Sheikh Zuwayed Station was to find methods to improve its cardenolide content and resistance. The results were successful, where phytochemical analysis (chromatographically using TLC + HPLC) of the plants every 3 months demonstrated qualitative similarity of cardenolides in both cultivated and wild plants. The drip-irrigation technique was found more favorable for vegetative [much healthier, taller and with a larger number of branches and broader leaves] and cardenolides production where the large scale production of this valuable medicinal plant can be assured especially in the wide deserts of Egypt.

Fluctuations in the cardenolide content were observed using HPLC analysis, this was probably due to climatic and seasonal changes, as the optimum concentrations were seen in June and December.

Germination of seeds under normal conditions doesn't exceed 50\% increasing to $90 \%$ in the dark, and the need for insects for fertilization could prevent the fruit formation. This encouraged the use of tissue culture technique for the possible continuous production [not limited by season, space or time] of this therapeutically important plant and its cardenolides the whole year round. Trials using different growth regulators -with variable incubation periods- and precursors were performed, demonstrating that BA and NAA gave variable calli colours at primary stages and calli growth values and rates determined for each experiment with cardenolide content using HPLC analysis indicated the presence of these cardenolide and a remarkable increase in their concentration after addition of progesterone hormone.

\section{References}

[1] Hardman, J.G., Limbird, L.E., Molinoff, P.B., Ruddon, R.W. and Gilman, G.A. The pharmacological basis of therapeutic. (Ninth edition 1999).

[2] Mc.Guffin, M., Hobbs, C., Upton, R. and Goldberg, A. Botanical safety handbook. (American Herbal products associations [AHPA] CRC press.1997). $138-141$

[3] Cheung, H.T.A. and Watson, T.R J.C.S. Perkin I. Stereochemistry of the hexosulose in cardenolide glycosides of Asclepiadaceae.1980, $2162-8$

[4] Hifnawy, MS et al., Pergularia tomentosa cardiotonic activity of different extracts, fractions \&isolated compounds IOSR journal of pharmacy and biological sciences, 9(1)Jan.2004

[5] Desoukey, SY, Hifnawy, MS, El-Hawary, SS Eldeen and Amer, Kh. F. M.Sc. Thesis, Faculty of Pharmacy, Cairo University. 1998.

[6] Täckholm, VD. Flora of Egypt, (Sc. (Stockholm) 2nd Ed, Published by Cairo University Printed by Cooperative Printing Company, Beirut. 1974)

[7] Hamdy, I. Hussein, Al.Rajhy D, El Shahawi FI and Hashem SM, molluscicidal activity of Pergularia tomentosa (L.) methyomyl and methiocarb, against land snails Taylor and Francis Ltd. Through: http://ernesto.ingentaselect.Com.V1=6161349/cl=119/nw=1/rpsv/cgi-bin/link..../p21. International J. Pest management 45 (3)2000, $211-3$.

[8] IDRC international development research center Wadi-Allaqui conservation area Environmental valuation and management of plants in Egypt. http://www.idrc.co.library/document/108310/chap5_e.html 
[9] Wallace, J.W. and Mansell, R.L. Recent advances in phytochemistry, Biochemical interaction between plants and insects, Plerum press. New York and London,1976, $93-167$.

[10] Olemy MM, Elhag H, El Domiaty M, Abdel Sattar, E, Al Azizi, MM and AlSaid, M S, Biotransformation of digitoxigenin by cell suspension cultures of Pergularia tomentosa and Ammi visnaga, Saudi Pharm. J. 2, 1994, 76 - 83.

[11] Gamborg O.L.; Miller R.A. and Ojima K. Nutrient of suspension cultures of soybean root cells Exp. Cell Reports. 50, 1968,151158.

[11] Claus, EP and Tyler, V.E.Jr Pharmacognosy Fifth Edition(1968). Through Abdel Azim, N.S. (1995) PH.D thesis (Chemical Studies on certain Gomphocarpus Species).

[10] Murshige, T and Skoog, F A revised medium for rapid growth and bioassay with tobacco tissue cultures. Physiologia Plantarum $15,1962,437-497$.

[13] Djoko, S. and Thornburg, R.W Isolation and characterization of UMf synthase mutants from haploid cell suspension of Nicotiana tabacum. Plant physiol. 99, 1992, 1216-1225.

[14] Dunk MN, Szoke E and Verzar-petri, G, The growth dynamic of callus tissue of root and leaf origin in Datura innoxia Mill. Acta Bot. Acd. Sci. Hung, 27, 1981, 325-33. 